\title{
Strategia komunikacyjna Konfederacji w wyborach w 2019 roku - próba rekonstrukcji
}

\author{
Communication strategy of Konfederacja \\ in the 2019 Elections - Attempt to Reconstruct
}

Stowa kluczowe: kampania wyborcza, strategia polityczna, strategia komunikacyjna, wybory do Parlamentu Europejskiego, wybory parlamentarne

Keywords: election campaign, political strategy, communication strategy, European Parliament elections, parliamentary elections

Abstrakt: Analiza działań wyborczych podjętych w roku 2019 przez Konfederację pozwala na przyjęcie założenia, że ugrupowania stanowiące polityczny trzon Konfederacji wypracowały spójny (także w wymiarze aksjologicznym), uwzględniający dwie kampanie plan strategiczny, którego zasadniczym celem było zaistnienie na polskim rynku politycznym (uzyskanie reprezentacji parlamentarnej). Jako sukces należy uznać zorganizowanie $i$ konsolidacje nowego ugrupowania politycznego zdolnego (organizacyjnie, kadrowo i programowo) do wypracowania strategii komunikacyjnej umożliwiającej podjęcie efektywnej rywalizacji w wyborach parlamentarnych.

Abstract: The analysis ofelectoral actions taken by Konfederacja [Confederation Liberty and Independence] party in 2019 leads to assumption that their core formation achieved a consistent (also regarding axiological dimension) strategic plan which included two

* ORCID ID: https://orcid.org/0000-0002-0355-4004, doktor habilitowany, profesor Uniwersytetu Śląskiego, dyrektor Instytutu Dziennikarstwa i Komunikacji Medialnej Uniwersytetu Śląskiego. Zainteresowania badawcze: komunikowanie polityczne (w szczególności: strategie komunikowania politycznego), marketing polityczny, teoria i praktyka propagandy politycznej, rywalizacja wyborcza w Polsce, mediatyzacja polityki. Członek Komitetu Nauk Politycznych PAN, członek Polskiego Towarzystwa Komunikacji Społecznej. Email: mariusz.kolczynski@us.edu.pl. 
campaigns and was aimed at arising on Polish political market (gaining parliamentary representation). Organization and consolidation of a new political formation, able (in terms of structure, resources and strategy) to create a communication strategy allowing them to effectively compete in parliamentary elections, should be regarded as considerable success.

Przystępując do analizy przedsięwzięć komunikacyjnych Konfederacji ${ }^{1}$ realizowanych $\mathrm{w}$ trakcie kampanii poprzedzających wybory do Parlamentu Europejskiego (26 maja 2019) oraz wybory parlamentarne (13 października 2019) należy - w pierwszej kolejności - rozstrzygnąć zasadniczą kwestię: czy, biorąc pod uwagę zmiany organizacyjne (mające odzwierciedlenie w oficjalnej nazwie zarejestrowanego komitetu wyborczego), można mówić o dwóch odrębnych strategiach działania (Konfederacji KORWiN Braun Liroy Narodowcy w wyborach do PE oraz Konfederacji Wolność i Niepodległość w wyborach do Sejmu), czy o jednolitej strategii wyborczej ugrupowania posiadającego stabilny rdzeń organizacyjny (KORWiN, Ruch Narodowy, Grzegorz Braun) obejmującej obydwie elekcje odbywające się w 2019 roku?

Obserwacja działań podjętych po zakończeniu eurowyborów zmierzających do utrzymania i rozwoju nowej marki politycznej, pozwala na przyjęcie założenia, że ugrupowania stanowiące polityczny trzon Konfederacji wypracowały spójny (także w wymiarze aksjologicznym), uwzględniający dwie kampanie plan strategiczny, którego zasadniczym celem było zaistnienie na polskim rynku politycznym (uzyskanie reprezentacji parlamentarnej) $)^{2}$. Co więcej, fundament oferty wyborczej Konfederacji stworzony został na podstawie wcześniejszych koncepcji programowo/ politycznych głównych podmiotów tworzących koalicję (KORWiN, Ruch Narodowy, G. Braun) prezentowanych przez wiodących polityków we wcześniejszych kampaniach wyborczych ${ }^{3}$.

Koncepcja utworzenia szerokiej koalicji ugrupowań „narodowo-wolnościowych” wraz z próbą pozycjonowania jako „prawicowej alternatywy” dla Prawa i Sprawiedliwości (zwłaszcza w kontekście wyborów do Parlamentu Europejskiego) była związana z procesami zachodzącymi na

${ }^{1}$ Analizie poddano materiały sygnowane przez Konfederację, emitowane za pośrednictwem mediów tradycyjnych (telewizji) oraz własnych kanałów internetowych.

${ }^{2} \mathrm{Z}$ możliwym do osiągnięcia celem komplementarnym $\mathrm{w}$ postaci uzyskania mandatów w Parlamencie Europejskim, przy wysokiej mobilizacji własnych wyborców i niskiej mobilizacji elektoratu wiodących podmiotów rynkowych rynkowych (patrz: casus Nowej Prawicy J. Korwin-Mikke w wyborach do PE w 2014 roku).

3 W różnych konstelacjach organizacyjnych, np. przez kolejne ugrupowania J. Korwin-Mikke. 
polskim rynku politycznym, przede wszystkim procesem konsolidacji organizacyjnej podmiotów uczestniczących w rywalizacji; konsolidacji przebiegającej na dwóch płaszczyznach: (1) pragmatyczno-konkurencyjnej (Koalicja Europejska) i/lub (2) aksjologicznej (Lewica Razem) - faktycznie wymuszającej przyjęcie tożsamej lub zbliżonej opcji strategicznej przez pozostałe podmioty ubiegające się o poparcie wyborców ${ }^{4}$; przy czym przypadek Konfederacji ilustrował wariant wzajemnego przenikania płaszczyzny konkurencyjnej iaksjologicznej w procesie tworzenia nowego ugrupowania oraz kreowania strategii wyborczej.

Kalendarz wyborczy w 2019 roku niewątpliwie sprzyjał realizacji zamierzonego celu rynkowego; układ: wybory do Parlamentu Europejskiego - wybory parlamentarne stwarzał możliwość opracowania dwuetapowej strategii wyborczej, zakładającej:

1) osiągnięcie w I etapie (kampania wyborcza do PE) rozpoznawalności rynkowej nowego ugrupowania wraz wyrazistym pozycjonowaniem jako prawicowej konkurencji dla PiS (cel minimum) oraz przekroczenie progu wyborczego i uzyskanie mandatów w PE (cel maksimum),

2) uzyskanie w II etapie reprezentacji sejmowej (cel minimum); osiągnięcie wyniku przekładającego się na realny wpływ na sprawowanie władzy (cel maksimum).

\section{Etap I. Wybory do Parlamentu Europejskiego}

Pozycjonowanie rynkowe poprzez kampanię wyborczą do Parlamentu Europejskiego można traktować jako sprawdzoną opcję działania w polskiej rzeczywistości politycznej - wystarczy wspomnieć wybory do PE z 2014 roku, w której ten wariant strategiczny wybrały (z zadowalającym skutkiem $^{5}$ ) trzy ugrupowania klasyfikowane jako prawicowe (Solidarna Polska Zbigniewa Ziobry, Polska Razem Jarosława Gowina, Nowa Prawica - Janusza Korwin-Mikke). Warto także zwrócić uwagę na doświadczenia kampanii wyborczej Solidarnej Polski Z. Ziobry, pozycjonującej się

${ }^{4}$ Zwięźle ujął ten problem Marek Jakubiak w trakcie wywiadu w programie „Kwadrans polityczny” w TVP1: „Mali musza sięłączyć, żeby być dużymi”, www.tvp.info/41617963 (30.05.2019).

${ }^{5}$ Nowa Prawica - J. Korwin-Mikke uzyskała 7,15\% głosów (4 mandaty eurodeputowanych); natomiast wynik wyborczy Solidarnej Polski Z. Ziobry $(3,98 \%)$ oraz Polski Razem J. Gowina $(3,16 \%)$ otworzył drogę tym ugrupowaniom do koalicji wyborczej (a w konsekwencji wyborów parlamentarnych - koalicji rządowej) z Prawem i Sprawiedliwością w ramach Zjednoczonej Prawicy. 
w 2014 roku jako prawicowa alternatywa dla PiS. „Plebiscytowy” kontekst wyborów (PiS kontra „zjednoczona opozycja”, ,najważniejsze wybory od 1989 roku") wymuszał na partii rządzącej złagodzenie przekazu (marginalizacji w przekazie kampanijnym kwestii mogących utrudniać pozyskanie poparcia wyborców niezdecydowanych), stwarzając tym samym możliwości ukierunkowania kampanii na radykalnie prawicowe segmenty elektoratu. Patrząc na kontekst wyborczy z innej perspektywy, istniało także poważne zagrożenie, że koncentracja wyborców oraz mediów na rywalizacji pomiędzy dwoma wielkimi blokami partyjnymi (Zjednoczona Prawica vs Koalicja Europejska) będzie skutecznie blokować możliwości ekspozycji własnej oferty rynkowej i zwrócenie uwagi wyborców na alternatywne propozycje polityczne nowego ugrupowania.

Proces kształtowania nowego ugrupowania zapoczątkowało podpisanie porozumienia pomiędzy partią KORWiN a Ruchem Narodowym w grudniu 2018 r.(06.12.); po dołączeniu - w styczniu 2019 - stowarzyszeń Grzegorza Brauna (Pobudka) i Piotra Liroya-Marca (Skuteczni) można mówić o zakończeniu zasadniczej fazy formowania koalicji (wzmocnionej w kolejnych miesiącach przez przystąpienie kolejnych rozpoznawalnych postaci polskiej polityki: Kai Godek, działaczki pro-life z Fundacji „Życie i Rodzina” - „ikony” ruchu antyaborcyjnego oraz Marka Jakubiaka z Federacji dla Rzeczypospolitej).

Poszukując genezy strategii komunikacyjnej (inspiracji strategicznej) Konfederacji w kampanii do Parlamentu Europejskiego w 2019 roku należałoby odnieść się do wyborów europejskich z 2014 roku, z dwóch zasadniczych powodów: (1) przypomnienia wyborczej efektywności antyunijnej retoryki Nowej Prawicy - Janusza Korwina-Mikke, (2) zwrócenia uwagi na pierwszą, w miarę profesjonalną kampanię telewizyjną Ruchu Narodowego (przekazy emitowano w blokach nieodpłatnych audycji wyborczych). Reminiscencje przyjętych wówczas rozwiązań kampanijnych były aż nadto widoczne w 2019 roku.

Przekaz wyborczy Nowej Prawicy oparty był na czterech filarach: antyunijności ${ }^{6}$ (podejście typowe europejskich partii skrajnych lub pozasystemowych: zdobycie reprezentacji w PE jako środek do destrukcji Unii Europejskiej) - negacji wartości europejskich - kontestacji polskiego systemu partyjnego (zwłaszcza monopolu POPiS-u) - osobistej popularności J. Korwin-Mikke. Stosunkowo mocno (w materiałach z udziałem

${ }^{6}$ Czasem w radykalnie skrajnym formacie, z użyciem sformułowań typu „[...] okupacja brukselskich pederastów" (J. Korwin-Mikke w materiale z nieodpłatnej audycji wyborczej wyemitowanej w TVP1, 21.05.2014). 
Konrada Berkowicza) eksponowano wątek zmiany pokoleniowej niezbędnej do uzdrowienia polskiej polityki.

Ruch Narodowy prowadził kampanię pod hasłem przewodnim „radykalna zmiana"; główne elementy oferty wyborczej: przywrócenie pełnej niepodległości i suwerenności Polski, wiara katolickai „normalna” rodzina, wymiana elit politycznych (kontestacja układu „okrągłego stołu”, ,narodowa" wersja anty POPiS-u), bezpieczeństwo Polski (odbudowa armii), konieczność zmiany pokoleniowej („,zas młodychpatriotów”).

Należy także podkreślić istotny wpływ koncepcji politycznych Grzegorza Brauna z wyborów prezydenckich w 2015 roku na ostateczny kształt strategii komunikacyjnej Konfederacji (szczególnie w kampanii przed wyborami do PE). Warto zwrócić uwagę na fakt, że pomimo bardzo słabego wyniku wyborczego (0,83\% głosów), G. Braun potrafił (głównie za pośrednictwem internetowych kanałów komunikowania ${ }^{7}$ ) zbudować swoją rozpoznawalność polityczną dzięki starannie przygotowanym (zwracała uwagę nie tylko treść, ale profesjonalna forma przekazu) materiałom wyborczym prezentującym - w precyzyjny i zrozumiały sposób katalog wartości konserwatywno-narodowych. Katalog, w którym spójnie połączono postulaty typowe dla kolejnych ugrupowań J. Korwin-Mikke z propozycjami eksponowanymi prze działaczy różnych odłamów środowisk narodowych. „Dziewiątka” G. Brauna (wiara - rodzina - własność, Kościół - szkoła - strzelnica, wolność - godność - tradycja) wraz z bardziej rozwiniętymi postulatami (tradycyjny model rodziny, nie dla „sodomii", zdecydowany sprzeciw wo bec aborcji, proste i niskie podatki, dostęp do broni palnej, zmiana sposobu finansowania partii politycznych, sprzeciw wobec żydowskich roszczeń) wskazywały podstawowe wartości możliwe do zaakceptowania przez różne środowiska narodowoprawicowe, które znalazły się poza orbitą Zjednoczonej Prawicy.

W tym kontekście można uznać, że pierwszy test nowych koncepcji rynkowych Konfederacji miał miejsce w trakcie kampanii poprzedzającej przedterminowe wybory prezydenta Gdańska (3 marca 2019). W materiałach kampanijnych startującego w wyborach Grzegorza Brauna przeważały przekazy ostro sformułowane, balansujące na granicy poprawności politycznej $^{8}$, z widocznymi akcentami antyunijnymi ${ }^{9}$. Jako fundament

\footnotetext{
${ }^{7} \mathrm{Na}$ temat funkcji komunikowania w Internecie zob. 0. Annusewicz, Funkcje komunikowania politycznego w Internecie, «Studia Politologiczne» 2009, vol. 14.

8 „[...] nie będą nas Niemcy i Żydzi uczyć historii”, „[...] nie będą zboczeńcy wychowywać naszych dzieci”, Gdańsk „[...] nie tęczowy, nie brunatny, nie czerwony tylko biało-czerwony".

${ }^{9}$ Obrona Gdańska „przed dyktatem eurokomuny”.
} 
aksjologiczny oferty politycznej G. Brauna można uznać triadę: wiara katolicka, tradycyjna rodzina, polska własność. Test wyborczy radykalnego przekazu wypadł całkiem dobrze - przy wysokiej frekwencji wyborczej $(48,98 \%)$ G. Braun uzyskał zaskakująco wysokie poparcie - 11,86\%, zwłaszcza biorąc pod uwage, że kontekst przedterminowych wyborów (po tragicznej śmierci prezydenta Gdańska Pawła Adamowicza) nie sprzyjał ekspozycji radykalnej oferty politycznej.

Przed wyborami do Parlamentu Europejskiego doszło do znaczącej modyfikacji układu sił na rynku politycznym - o poparcie wyborców ubiegały się cztery nowo powstałe komitety wyborcze (zjednoczona opozycja w nowym formacie Koalicji Europejskiej [Platforma Obywatelska na bazie wcześniejszych doświadczeń - kontestacji działań podejmowanych przez PiS - doprowadziła do powstania szerokiej koalicji wyborczej, w skład której wchodziły: Platforma Obywatelska, .Nowoczesna, Sojusz Lewicy Demokratycznej, Polskie Stronnictwo Ludowe, Partia Zieloni oraz szereg mniejszych ugrupowań10], Komitet Wyborczy Lewica Razem ${ }^{11}$, Komitet Wyborczy Wiosna Roberta Biedronia oraz Konfederacja), stąd bardzo interesująco przedstawiały się kluczowe kwestie: jaką pozycję rynkową (w wymiarze konkurencyjnym i problemowym) zajmą poszczególne ugrupowania oraz, w jaki sposób będą komunikowały z potencjalnymi wyborcami. Nie należy przy tym zapominać, że kampania poprzedzająca wybory do Parlamentu Europejskiego w 2019 roku odbywała w szczególnie złożonym kontekście sytuacyjnym. Przede wszystkim każdy z liczących się podmiotów politycznych musiał brać pod uwagę fakt, że wybory europejskie, oprócz bieżącego wymiaru rywalizacji wyborczej będą stanowiły generalną próbę przed jesiennymi wyborami parlamentarnymi. Należało zatem podjąć decyzję (trudną w przypadku ugrupowań, których celem było przekroczenie progu wyborczego) odnośnie horyzontu czasowego strategii (dwie strategie przygotowane na kolejne elekcje lub spójna strategia zorientowana na sukces w wyborach parlamentarnych) oraz sposobu pozycjonowania konkurencyjnego na scenie politycznej.

Sposób przygotowania i realizacji kolejnych przedsięwzięć kampanijnych pozwala na całościowe spojrzenie na strategię Konfederacji, z wyraźnym wyróżnieniem dwóch podstawowych faz strategicznych:

- faza I: obejmująca okres tworzenia koalicji oraz formułowania przekazu początkowego (oferty wyjściowej) przed wyborami do PE;

10 Najbardziej znaczące: Inicjatywa Polska Barbary Nowackiej.

${ }^{11}$ Komitet tworzyły: Partia Razem-Unia Pracy-Ruch Sprawiedliwości Społecznej. 
główne cele strategiczne: kształtowanie rozpoznawalności rynkowej, pozycjonowanie rynkowe (prawicowa alternatywa dla PiS) oraz mobilizacja potencjalnego elektoratu; ukierunkowanie strategii: negatywne, - faza II: obejmująca okres modyfikacji struktury organizacyjnej po wyborach do PE oraz kreacji zasadniczej oferty wyborczej; ukierunkowanie strategii: mieszane, $\mathrm{z}$ dominującą orientacją pozytywną (koncentracji w przekazie na własnej ofercie politycznej).

Komitet Wyborczy Konfederacja KORWiN Liroy Braun Narodowcy przygotowując strategię kampanii wyborczej do Parlamentu Europejskiego stanął przed poważnym wyzwaniem, w jaki sposób stworzyćspójną ofertę wyborczą (spójny przekaz kampanijny) przy tak wyraźnym zróżnicowaniu aksjologicznym podmiotów tworzących koalicję. Oczywiście można „zaklinać" rzeczywistość, jak to czynił wielokrotnie Piotr Liroy Marzec („pięknie się różnimy”) oraz działać z przekonaniem, że Konfederacja jest największym sojuszem ugrupowań narodowych, wolnościowych i ruchów obywatelskich po 1989 roku (Robert Winnicki) - jednakże efektywna kampania wyborcza wymaga od podmiotów uczestniczących jasnego i czytelnego w odbiorze przesłania kampanijnego oraz profesjonalnej koordynacji i kontroli działań podejmowanych przez poszczególnych reprezentantów Koalicji.

Analiza zrealizowanych przedsięwzięć wyborczych wskazuje, że zdecydowano się na jedyny możliwy (ze względu na bardzo późne ukształtowanie ostatecznego składu Komitetu Wyborczego) wariant strategii ostrego finiszu, rozpisanej na trzy główne kanały komunikowania' ${ }^{12}$ : bezpośredni (spotkania z wyborcami zawsze były mocną stroną kolejnych inicjatyw politycznych J. Korin-Mikke), internetowy (stosunkowo wysoka aktywność, przy niewysokim poziomie koordynacji działań) oraz telewizyjny (Konfederacja, jako jeden z nielicznym komitetów wyborczych, przygotowała urozmaicony formalnie i merytorycznie zestaw materiałów kampanijnych emitowanych w trakcie bloków nieodpłatnych audycji wyborczych w TVP1, TVP2 oraz TVP Polonia'i3).

12 Na temat marketingu relacji zob. E.M. Marciniak, Relacyjnateoriakomunikacjiamarketing relacji w polityce, «Studia Politologiczne» 2012, vol. 24.

13 Nieodpłatne audycje wyborcze Konfederacji odbiegały pozytywnie od wzorca „monotonnej replikacji” zaprezentowanego przez inne komitety walczące o przekroczenie progu wyborczego: KWKukiz'15, KWLewica Razem, KWWiosna Roberta Biedronia, zob.szerzej: M. Kolczyński, Niechciany reliktery premarketingowejw rywalizacji politycznej - nieodpłatne audycje komitetów wyborczych w telewizji publicznej w wyborach do Parlamentu Europejskiego'2019, [w:] M. Kolczyński (red.), Najważniejszewyboryod1989 roku? Wybory doParlamentuEuropejskiegow2019 roku:wybraneaspekty kampaniiwyborczej, Toruń2019. 
Rysunek 1. Strategia komunikacyjna Konfederacja KORWiN Liroy Braun Narodowcy (I Faza - wybory do Parlamentu Europejskiego

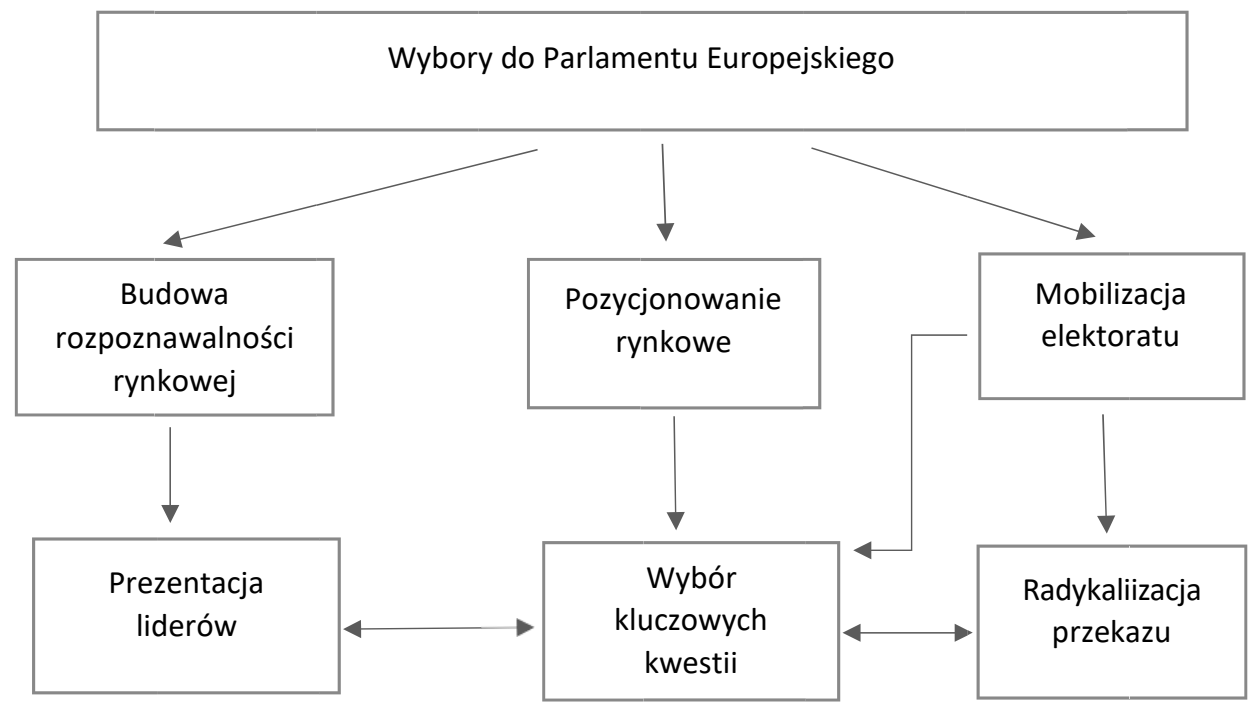

Źródło: opracowanie własne.

Mocnym elementem kampanii Konfederacji były działania bezpośrednie, a trzy z nich: „Wielka” Konwencja Wyborcza (6 kwietnia 2019), „wielki”14 Marsz Suwerenności (1 maja 2019) oraz Marsz \#Stop447 (11 maja 2019) należy uznać jako definiujące przekaz ugrupowania na finiszu kampanii wyborczej. Co ważniejsze, wydarzenia nie tylko w profesjonalny sposób wprowadzane informacyjnie oraz relacjonowane przez własne media internetowe (Facebook, Youtube, Twitter), ale także uzyskujące zadowalającą ekspozycję w mediach tradycyjnych ${ }^{15}$. Porównując obydwa wydarzenia, nie można także nie zauważyć sposobu, w jaki dokonywano szybkiej modyfikacji przekazu kampanijnego (radykalizacja treści przewodnich).

14 Przymiotnik „wielki” pojawia się w zapowiedziach i relacjach z konwencji oraz marszu w mediach społecznościowych; w przypadku Konwencji - porównując jej rozmach z konwencjami wiodących podmiotów politycznych - określenie „wielka” nie oddaje rzeczywistego charakteru wydarzenia, zob.: www.youtube.com/watch?v=mKlhcfmK5Sc (30.05.2019).

15 Kontrowersyjny charakter przesłania Marszu Suwerenności oraz próba zablokowania Marszu przez Prezydenta Warszawy sprzyjały ekspozycji w telewizyjnych programach informacyjnych. Nie bez znaczenia było anty-PiSowskie pozycjonowanie rynkowe Konfederacji. 
Pierwszomajowy Marsz Suwerenności odbywał się w 15. rocznicę uzyskania członkostwa w Unii Europejskiej16; w przekazie dominowały dwie grupy wartości:

1) antyunijne (w hasłowym ujęciu: „Nie dla UE”) - rozpisane na populistyczne postulaty obrony niepodległości Polski przed zakusami „brukselskich komisarzy" oraz obrony suwerenności politycznej, kulturowej i gospodarczej,

2) antyestablishmentowe (w hasłowym ujęciu: „PiS PO jedno zło”). Jednym z celów Marszu (podobnie jak wcześniejszej Konwencji Wyborczej) była prezentacja liderów koalicji, wraz ze wskazaniem zróżnicowanego charakteru ugrupowania łączącego ruchy wolnościowe, narodowe i pro life (materiały z Marszu stanowiły osnowę pierwszych nieodpłatnych audycji wyborczych w TVP).

O ile Marsz Suwerenności można uznać za przejaw wyrazistego pozycjonowania względem Prawa i Sprawiedliwości, o tyle przesłanie Marszu \#Stop447 skierowane było do najbardziej radykalnych segmentów elektoratu prawicowego/narodowego, umiejętnie wykorzystując resentymenty antyżydowskie/antyizraelskie w kontekście tzw. Ustawy 447 (Justicefor Uncompensated Survivors Today Act of 201717) wprowadzono temat obrony przed roszczeniami organizacji żydowskich (z tytułu rekompensaty za tzw. mienie bezspadkowe) sięgającymi 300 miliardów dolarów (przekaz „wzbogacony” o wyraźny wątek antyamerykański).

Bardzo czytelną strategię przyjęto przygotowując materiały do bloków nieodpłatnych audycji wyborczych emitowanych w TVP18. Można wyróżnić trzy zasadnicze etapy strategii w tym obszarze działania:

I etap wprowadzający (11.05-15.05) - emitowane przekazy miały charakter informacyjno-prezentacyjny, z widocznym zogniskowaniem treści wokół oferty programowo-personalnej własnego ugrupowania. Zasadniczym celem pierwszych audycji było przedstawienie liderów ugrupowania oraz ekspozycja głównych postulatów programowych lub odwołanie do fundamentalnych wartości, z jednoczesną próbą powiązania poszczególnych propozycji programowych z osobami liderów ugrupowań i organizacji współtworzących Konfederację:

1) antysystemowość (lider symboliczny: Janusz Korwin-Mikke), z rozróżnieniem dwóch układów kontekstowych: (a) krajowego (Konfede-

16 Według J. Korwin-Mikke 15. rocznicę Anschlussu Polski, www.facebook.com/wat$\mathrm{ch} / \mathrm{v}=768250660227496$ (30.04.2019).

17 www.congress.gov/bill/115th-congress/senate-bill/447 (30.05.2019).

18 Zob. także: M. Kolczyński, Niechciany relikt ery premarketingowej... 
racja jako jedyne ugrupowanie antysystemowe i faktycznie prawicowe na polskim rynku politycznym; podkreślenie nieskomplikowanego charakteru podziału polskiej sceny politycznej: Konfederacja vs partie lewicowe [partie układu „okrągłego stołu”] ${ }^{19}$, (b) unijnego, z mocną kontestacją funkcjonowania Unii Europejskiej - porównanie stopnia podporządkowania obywateli w systemie UE do systemu stalinowskiego; z mediami masowymi jako głównym instrumentem „obywatelskiego zniewolenia",

2) obrona suwerenności Polski (lider symboliczny: Marek Jakubiak),

3) obrona fundamentalnych wartości społecznych (lider symboliczny: Kaja Godek); przesłanie - Konfederacja jako jedyne ugrupowanie (władza konserwatystów i liberałów „zużyła się”) walczące o wartości podstawowe (w tym prawo do życia),

4) walka o wielką, wolną, dumną i niepodległą Polskę (lider symboliczny: Robert Winnicki),

5) bezkompromisowość (lider symbloliczny: Grzegorz Braun), obrona interesów Polski przed wrogimi siłami zewnętrznymi („eurosowieciarzami” oraz „imperialistami ze Wschodu i Zachodu”),

6) działanie na rzecz dobra wspólnego (lider symboliczny: Piotr Liroy Marzec), podkreślenie wspólnoty celówi wartości (pomimo wewnętrznego zróżnicowania).

II etap zogniskowania i radykalizacji przekazu (16.05-19.05) - etap, w którym dominują mocne przekazy negatywne ${ }^{20}$; widoczna koncentracja na konkretnych, wyselekcjonowanych pod kątem oczekiwań potencjalnych wyborców ${ }^{21}$, problemach wewnątrzkrajowych i ogólnoeuropejskich, prezentowanych $\mathrm{w}$ radykalnym formacie interpretacyjnym; zakończono fazę prezentacji poszczególnych liderów ${ }^{22}$. Nowy format audycji obejmował cztery, wzajemnie powiązane, segmenty tematyczne ${ }^{23}$ :

1) segment anty-PiSowski,

2) segment antyestablishmentowy,

3) segment antyunijny,

4) segment aksjologiczno-konkurencyjny (zob. rysunek 2).

${ }^{19}$ Do tej grupy J. Korwin-Mikke zaliczył wszystkie partie poza Konfederacją.

${ }^{20}$ Na temat zjawiska tzw. hejtu internetowego zob. M. Kolczyński, Hejt internetowy jako narzędzie dekompozycji wizerunku politycznego, «Studia Politologiczne» 2017, vol. 45.

${ }^{21}$ Format wskazywałby, że przekazy były adresowane do skrajnego elektoratu prawicowego.

$22 \mathrm{Z}$ silną ekspozycją G. Brauna w roli narratora kolejnych audycji.

23 Prezentowany układ dotyczył audycji emitowanych w TVP 1 (format $30 \mathrm{~min}$.); w TVP 2 tematyka tożsama, kolejność prezentacji zmienna. 
Rysunek 2. Ukierunkowanie przekazów negatywnych Konfederacji w nieodpłatnych audycjach wyborczych (wybory do PE '2019)

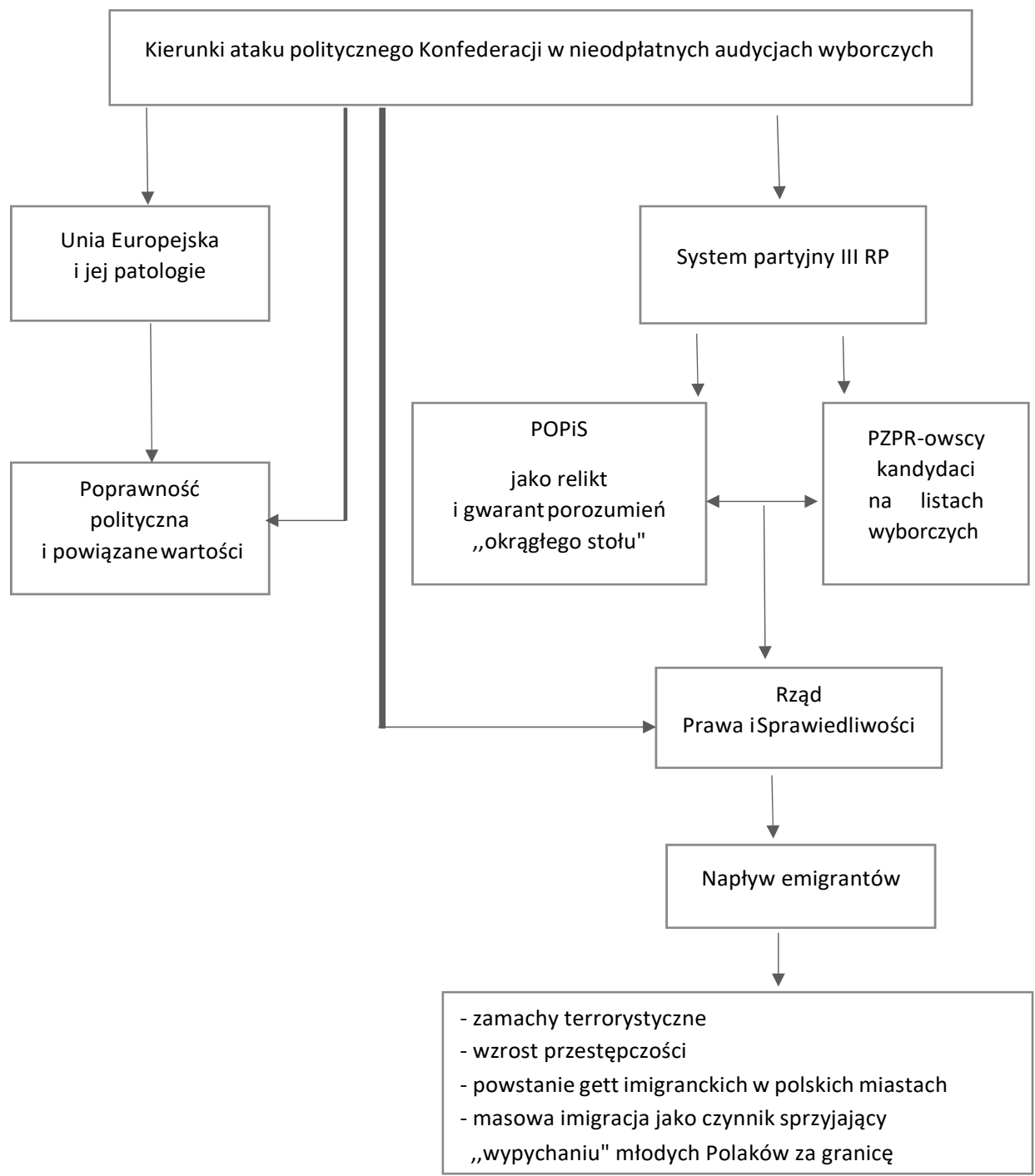

Źródło: opracowanie własne.

Każdy segment składał się z części przedstawiającej problem i jego determinanty systemowe oraz części wskazującej Konfederację jako ugrupowanie posiadające przygotowane określone rozwiązania polityczne (w materiałach brak szczegółowych odniesień do konkretnych propozycji).

Główne kierunki ataku na rząd Prawa i Sprawiedliwości: niedotrzymanie obietnic przedwyborczych dotyczących zatrzymania napływu 
imigrantów do Polski; przekonujący przekaz (wsparty umiejętnie wykorzystanymi infografikami) o „zalewie imigrantów” i jego potencjalnych konsekwencjach (zamachy terrorystyczne, wzrost przestępczości, powstanie gett imigranckich w polskich miastach, masowa imigracja jako czynnik sprzyjający „wypychaniu” młodych Polaków za granicę).

W segmencie antyestablishmentowym: w centrum ataku PO oraz PiS jako podmioty broniące układu „okrągłego stołu”, trwające w pozorowanym konflikcie w celu utrzymania politycznego status quo, z istotnym udziałem polityków o PZPR-owskiej proweniencji ${ }^{24}$.

W odniesieniu do UE przywołano negatywne (w ocenie polityków Konfederacji) konsekwencje polskiego członkostwa w UE: utratę suwerenności, ograniczenie konkurencyjności polskiej gospodarki, nieuzasadnione ingerencje w polskie prawodawstwo, narzucanie niekorzystnych dla Polski rozwiązań w zakresie polityki klimatyczneje ${ }^{25}$, tolerowanie specjalnej roli Niemiec i ich specjalnych relacji gospodarczych z Rosją.

W segmencie aksjologicznym - ponownie eksponowano antywartości „narzucane” przez UE (ideologia gender, aborcja, homolobby, poprawność polityczna, marksizm kulturowy), z dobrze ilustrowanym odniesieniem konkurencyjnym ${ }^{26}$ oraz mocnym podsumowaniem: Konfederacja obroni polską rodzinę, ,"nie będą zboczeńcy wychowywać naszych dzieci”.

III etap ostrego finiszu kampanii, z silnym przekazem negatywnym oraz wprowadzeniem nowych wątków problemowych (np. \#STOP447).

Różnorodność poruszanej problematyki nie sprzyjała utrzymaniu zwartej formy przekazu i świadczyła o braku czytelnej koncepcji zakończenia kampanii w telewizji publicznej, sprowadzającej się do dalszego zaostrzenia retoryki wyborczej, w tym wykorzystania niemalże karykaturalnej argumentacji:

1) przekaz antyestablishmentowy: brak prawdziwej prawicy w Polsce jako konsekwencja porozumień „okrągłego stołu” i pochodnej „doktryny Kiszczaka",

24 Trafne odwołanie do kształtu list wyborczych Koalicji Europejskiej, na których zarezerwowano eksponowane miejsca dla byłych działaczy PZPR.

25 Przemyślany przykład przedstawiony w ciągu przyczynowo-skutkowym: unijna polityka klimatyczna $\rightarrow$ problemy polskiej energetyki $\rightarrow$ podwyżki cen prądu dla klientów detalicznych.

26Wskazano partie popierające wprowadzanie („wrogowie cywilizacji”) tych wartości do Polski (np. PO, Wiosna popierające kartę LGBT+) oraz zaniechań PiS („obłudny PiS”) w przeciwdziałaniu tym trendom. 
2) przekaz antyunijny: zogniskowanie na kryzysie UE i jego konsekwencjach: rosnącej biurokracji, spadku konkurencyjności gospodarczej, zagrożeniu wolności w Internecie,

3) mocny przekaz antyaborcyjny (K. Godek),

4) katalog zarzutów wobec Prawa i Sprawiedliwości poszerzono o: zarzut uległości wobec USA ${ }^{27}$, Izraela ${ }^{28}$ oraz brak koncepcji polityki zagranicznej29.

5) przekaz aksjologiczny zaprezentowany w końcowej fazie kampanii można określić jako swoisty polityczny patchwork G. Brauna: (a) „nie dla żydowskich roszczeń30" - tak dla polskiej własności i przedsiębiorczości, (b) credo Konfederacji: za życiem, za suwerennością, za bezpieczeństwem wiary, rodziny, własności; nie ma zgody na to, aby: Niemcy i Żydzi uczyli nas historii Polski, eurosowieciarze pouczali jak rządzić Polską, „zboczeńcy wychowywali nasze dzieci”.

Warto odnotować profesjonalną koordynację przedsięwzięć realizowanych za pośrednictwem różnych kanałów medialnych - zwraca uwagę sposób uporządkowania przekazu w internetowych kanałach komunikowania; jako szczególnie dobry przykład można uznać własny kanał Konfederacji w serwisie YouTube. Oprócz materiałów bieżących wyeksponowano umieszczone w serwisie spoty wyborcze koalicji: sześć spotów zawiera w skondensowanej formie podstawowe elementy oferty wyborczej: prezentacja liderów ugrupowania (spot nr 1: „Sześciu liderów”) - sprzeciw wobec narzucanych prze UE wartościom, z silny wątkiem antyestablishmentowym (spot nr 2: Konfederacjaw obronie Rodziny!) - sprzeciw wobec masowej imigracji i biernością władz polskich w tym zakresie (spot nr 3: Stopmasowejimigracji!) - kontestacja układu „okrągłego stołu” (spot nr 4: Konfederacja rozbije Układ!) - kontestacja sposobu funkcjonowania UE (spot nr 5: Konfederacja przywróci Polsce Suwerenność!) - sprzeciw wobec

27 „PiS przyjął status lokaja Waszyngtonu” [G. Braun], brak reakcji na ustawę 447, nieuprawnione naciski ambasador USA G. Mosbacher w obronie/promowaniu interesów amerykańskich firm, zorganizowanie - pod naciskiem USA - konferencji bliskowschodniej w Warszawie skierowanej przeciwko Iranowi.

${ }^{28}$ J. Korwin Mikke: „Głos na PiS, to głos na Benjamina Netanjahu”, głos na PiS, to konieczność spłaty roszczeń żydowskich; G. Braun: wycofanie nowelizacji ustawy o IPN [decyzja podjęta po „negocjacjach prowadzonych w tajnej siedzibie Mosadu”].

29 G. Braun: „PiS obiecywał wstawanie z kolan, a upadł na twarz”; w dalszej części audycji padało pytanie: czy chcemy powierzyć polską politykę zagraniczną „,chłopcom w krótkich spodenkach", którym brak elementarnej odwagi, honoru i woli by wstać z kolan?

${ }^{30} \mathrm{Z}$ kontrowersyjnym wątkiem odnoszącym się do kłamstw na temat udziału Polaków w Holokauście, mającym na celu wyłudzenie od Polski 300 mld \$. 
uległości polskiego rządu wobec USA, Izraela (spot nr 6: NIE dla obcych roszczeń!) ${ }^{31}$.

Trudno jednoznacznie ocenić wynik wyborczy Konfederacji KORWiN Braun Liroy Narodowcy (4,55\%, 621188 głosów). Z jednej strony, nie powtórzono sukcesu Nowej Prawicy J. Korwin-Mikke z 2014 roku; trudno także uznać za zadowalający poziom mobilizacji własnego elektoratu przy prawie dwukrotnie wyższej frekwencji wyborczej połączonym siłom radykalnej prawicy udało się zwiększyć stan posiadania raptem o prawie siedemnaście tysięcy głosów ${ }^{32}$. Z drugiej strony, za niewątpliwy sukces należy uznać: (1) stworzenie nowego ugrupowania i utrzymanie jego organizacyjnej spójności przez cały okres kampanii, (2) wykreowanie nowej marki na rynku politycznym, (3) zajęcie czytelnej w społecznym odbiorze pozycji rynkowej (prawicowa alternatywa dla PiS) oraz (4) stworzenie katalogu wartości integrujących ugrupowania prawicowe o zróżnicowanym rodowodzie politycznym. Innymi słowy, osiągnięto w pierwszym etapie cele minimalne: zorganizowania i konsolidacji nowego ugrupowania politycznego zdolnego (organizacyjnie, kadrowo i programowo) do podjęcia rywalizacji w wyborach parlamentarnych.

\section{II etap. Wybory do Sejmu i Senatu}

Początek drugiego etapu realizacji strategii Konfederacji świadczył o odpowiednio wysokim stopniu integracji ugrupowania i konsekwentnym dążeniu maksymalnie szybkiego przygotowania nośnej rynkowo oferty wyborczej. Niespełna miesiąc po wyborach do Parlamentu Europejskiego przedstawiono (konferencja prasowa w Sejmie, materiały umieszczone w mediach społecznościowych ${ }^{33}$ ) podstawowe założenia zmodyfikowanej oferty rynkowej ( 7 tez programowych Konfederacji, 18 czerwca 2019):

1) suwerenne państwo z silną armią i polską walutą,

2) ochrona życia ludzkiego od poczęcia,

3) proste i niskie podatki,

4) ochrona dzieci i młodzieży przed homopropagandą,

31 Zgodnie ze sprawozdaniem finansowym złożonym w Państwowej Komisji Wyborczej Konfederacja wydała na emisję reklam w Internecie 519 043,04 zlp, www.pkw.gov.pl/ pliki/1570540236_20_KWW_Konfederacja_Korwin_Braun_Liroy_Narodowcy.pdf (20.01.2020).

32 Łączna liczba głosów oddana na Nową Prawicę J. Korwin-Mikke i Ruch Narodowy w 2014 roku: 604212.

33 https://www.facebook.com/jkm.wolnosc/videos/2791766130850622/ (20.06.2019). 
5) sprzeciw wobec bezpodstawnych żydowskich roszczeń majątkowych,

6) kara śmierci za najcięższe zbrodnie,

7) e-voting.

W porównaniu do wcześniejszych postulatów pojawiły się nowe elementy programowe, z których zwracał uwagę projekt zmiany systemu podatkowego (rozwijany konsekwentnie w trakcie kampanii wyborczej).

Roszady personalne ${ }^{34} \mathrm{w}$ ugrupowaniu oraz pochodne dylematy organizacyjne ${ }^{35}$ sprawiły, że ponownie przyjęto wariant strategii ostrego finiszu; faktyczne rozpoczęcie intensywnych działań przypadało na Konwencję Wyborczą partii (21.09.). Konwencja przyniosła istotną zmianę strategii komunikacyjnej; zmianę widoczną zarówno w ofercie programowej Konfederacji (zaprezentowane w trakcie Konwencji nowe propozycje programowe: „Piątka Konfederacji”), jaki w sposobie prezentacji (przedstawienie założeń programowych powierzono młodym liderom Konfederacji, uwiarygodniając - w społecznym odbiorze - zwrot strategiczny) ${ }^{36}$.

Kluczowym momentem Konwencji była prezentacja nowego spotu wyborczego Piattka Konfederacji zawierającego (w hasłowym ujęciu) nowe propozycje programowe:

1) "1000+" Powszechna ulga podatkowa (likwidacja podatku PIT, dobrowolny ZUS, benzyna po 3 złote),

2) Szybkie i sprawiedliwe sądy (parametryzacja sądów, cyfryzacja sądownictwa, uproszczenie procedur),

3) Bon oświatowy i kulturalny (decydująca rola rodziców w kwestiach wychowania i edukacji, podniesienie jakości edukacji, zatrzymanie propagandy LGTB),

4) Bezpieczeństwo narodowe (silna polska armia, asertywna i niezależna polityka zagraniczna, bezpieczeństwo energetyczne - z docelowym przestawieniem na energetykę jądrową, odpowiedzialna polityka migracyjna),

5) Zdroweżycie (poprawa funkcjonowania służby zdrowia, ochronażycia poczętego, walka o czyste powietrze, zakaz importu śmieci, promocja masowego sportu).

${ }^{34} \mathrm{Na}$ poziom konsolidacji nie miały wpływu roszady personalne; jednakże odejście M. Jakubiaka, P.Liroya-Marca i K. Godek niewątpliwie przyczyniło się do spowolnienia realizacji kolejnych przedsięwzięć wpisanych w strategię kampanii.

35 Rozstrzygnięte dopiero wraz z zarejestrowaniem przez sąd (25.07.) partii Konfederacja Wolnośći Niepodległość, rejestracją partyjnego komitetu wyborczego (12.08.) oraz skuteczną kampanią prowadzącą do rejestracji list kandydatów we wszystkich okręgach wyborczych.

${ }^{36}$ Zob. www.youtube.com/watch?v=WHky705SwVo (20.01.2020). 
Przedstawiona oferta wyborcza różniła się znacząco od wcześniejszych „7 tez programowych Konfederacji”, kładąc nacisk na propozycje pozytywnych rozwiązań systemowych (np. w kwestiach podatkowych lub bezpieczeństwa), subtelnie marginalizując niektóre kontrowersyjne kwestie światopoglądowe (np. włączenie postulatu ochrony życia poczętego w pakiet propozycji dotyczących zdrowego życia). Zwracało uwagę włączenie do programu problematyki stanowiącej ważny obszar dyskursu kampanijnego (zwłaszcza na płaszczyźnie rywalizacji pomiędzy Prawem i Sprawiedliwością a Koalicją Obywatelską): stanu polskiej służby zdrowia oraz kwestii ekologicznych (walka ze smogiem, import śmieci).

Godnym odnotowania (zwłaszcza pamiętając o profilu socjo-demograficznym elektoratu Konfederacji) był fakt powierzenia roli głównych mówców, prezentujących kolejne elementy programu, politykom młodej generacji polskiej prawicy: Jakubowi Kuleszy (1000+), Michałowi Wawrowi (naprawa sądownictwa), Konradowi Berkowiczowi (kwestie oświaty i wychowania), Witoldowi Tumanowiczowi (kwestie bezpieczeństwa narodowego) ora Krzysztofowi Bosakowi (zdrowe życie). Poczet młodych liderów uzupełniał Sławomir Mentzen prezentujący Pakiet Polskiego Przedsiębiorcy (z kluczowym projektem nowej ordynacji gospodarczej).

Dopiero w dalszej kolejności zabrali głos inni liderzy: J. Korwin-Mikke, G. Braun i R., Winnicki; agresywne, szczególnie w części poświęconej zwalczaniu ideologii LGBT, wystąpienie J. Korwin-Mikke niewątpliwie nie przystawało do podjętej próby modyfikacji wizerunku ugrupowania, w pewnym sensie zaburzając pozytywny wydźwięk pierwszej części Konwencji.

W interesujący sposób sformatowano przekaz w partyjnych spotach wyborczych; poza kluczową reklamą nowej oferty politycznej (spot Piątka Konfederacji) warto zwrócić uwagę na trzy inne spoty reklamowe:

1) Konfederacja Wolność i Niepodległość to największa obniżka podatków $w$ historii Polski! piętnujący obciążenia fiskalne, wadliwe czy wręcz patologiczne mechanizmy redystrybucji środków uzyskanych z podatków ${ }^{37}$, prezentując na tym tle korzyści z proponowanej powszechnej ulgi podatkowej $(1000+)$,

2) Konfederacja Wolność i Niepodległość rozbije układ III RP - Damy radę! z mocnym atakiem na „układ okrągłego stołu, przy jednoczesnym

37 W wyrazisty sposób zdefiniowano „korzyści” czerpane przez przeciętnego podatnika: śmieciowe emerytury, „przywilej umierania w kolejce do lekarza”, pseudoedukacja, niewydolne sądy, dziurawe drogi; natomiast jako beneficjentów systemu podatkowego wskazano: „armię urzędników”, ,kastę polityków” oraz „masę nierobów”. 
negatywnym odniesieniu do jakości rządów Prawa i Sprawiedliwości (z powtarzanym jak mantra zwrotem „PiS nie dał rady” po każdym segmencie tematycznym) oraz działań „totalnej opozycji”,

3) chyba najciekawszy w zestawie spotów KonfederacjaWolnośći Niepodległość jedyna siła antysystemowa!, znakomicie pozycjonujący Konfederację na tle Koalicji Polskiej (PSL-Kukiz'15) - podważający koniunkturalną antysystemowość Pawła Kukiza i kuriozalny charakter tej koalicji (PSL jako partia najdłużej zakorzeniona w układzie władzy „okrągłego stołu”, przeciwna jednomandatowym okręgom wyborczym, znaczący element „totalnej opozycji”), z konkluzją zawartą w tytule spotu.

W blokach nieodpłatnych audycji wyborczych emitowanych w telewizji publicznej Konfederacja, w przeciwieństwie do kampanii poprzedzającej wybory do Parlamentu Europejskiego Konfederacja, przedstawiła dwa warianty formatowania przekazu wyborczego:

1) wariant powtarzalnego, zogniskowanego programowo przekazu (w pierwszym tygodniu emisji audycji), w którym wykorzystywano materiały z Konwencji Wyborczej z udziałem polityków ugrupowania (J. Kulesza, M. Wawer, W.Tumanowicz, K. Bosak, K. Berkowicz oraz S. Mentzen; przy czym kolejność prezentacji ulegała zmianom) prezentujących podstawowe założenia „Piątki Konfederacji”, uzupełniane wypowiedziami S. Mentzena na temat Pakietu Polskiego Przedsiębiorcy,

2) wariant pop-polityczny (w drugim tygodniu emisji audycji), ograniczający się de facto do emisji teledysku wyborczego Na Konfederację oddaj głos królewno! utrzymanego w stylistyce muzycznej disco-polo 38 . Prosty (odpowiadający stylistyce tego rodzaju muzyki) tekst z jednej strony agituje na rzecz Konfederacji („Obniżą, obniżą, obniżą nam podatki!, W portfelu większy hajs, zostanie na wydatki, I puka i puka i puka ktoś do drzwi 'stop imigrantom' to podpowiada mi!"), w warstwie obrazowej: czołowi politycy ugrupowania; z drugiej - w mało wybredny sposób atakuje oponentów politycznych ${ }^{39}$, z niezbyt subtelnymi odniesieniami wizualnymi. Pomijając odczucia estetyczne, należy przyznać, że teledysk równocześnie umieszczony w interne-

38 Teledysk nawiązuje w warstwie muzycznej do internetowego przeboju lata '2019 „Ona by tak chciała” (około 70 mln odtworzeń do początku października), autor: Ronnie Ferrari (Hubert Kacperski).

${ }^{39} \mathrm{~Np}$. PiS: „Kaczyński obiecuje, pięćset Wam podaruje, lecz o tym już nie wspomni, ile wam zajebuje”; PO: „PeOwce te złodzieje odsunięci już od myta. Tak kwiczą, bo to świnie oderwane od koryta”; Lewica: „Lewica - komuniści i Marksiści oraz geje. Gdy słyszę ich pomysły to się tylko głośno śmieję”. 
cie okazał się niezwykle efektywnym viralem, przewyższającym wielokrotnie popularnością (blisko 800 tys. wyświetleń w serwisie YT) jakikolwiek inny materiał wyborczy sygnowany przez Konfederację. Warto odnotować, że wraz z umacnianiem pozycji sondażowej w trakcie kampanii wyborczej, znacznie poprawiła się medialna ekspozycja Konfederacji, szczególne znaczenie miał rosnący udział polityków Konfederacji w programach telewizji komercyjnych, przy widocznej i celowej marginalizacji ugrupowania w kanałach telewizji publicznej ${ }^{40}$.

Wynik wyborów parlamentarnych (6,81\% głosów, 11 mandatów sejmowych) pozwala pozytywnie ocenić przyjętą strategię komunikacyjną. Tym niemniej, osiągnięty rezultat - przy wysokości poparcia dla innych ugrupowań - można ocenić jako realizację celu minimum, (uzyskania reprezentacji parlamentarnej) przy ograniczonym realnym wpływie politycznym i mało komfortowej pozycji strategicznej pomiędzy rządzącym PiS a pozostałymi siłami opozycyjnymi w Sejmie. Niewątpliwie główną barierą uniemożliwiającą przyjęcie bardziej aktywnej strategii komunikacyjnej był brak środków, faktycznie wykluczający rozwinięcie kampanii w mediach tradycyjnych, odgrywających (jeszcze) decydującą rolą w polskich kampaniach wyborczych.

\section{Bibliografia}

0. Annusewicz, Funkcje komunikowania politycznego w Internecie, «Studia Politologiczne» 2009, vol. 14.

M. Kolczyński, Hejt internetowy jako narzędzie dekompozycji wizerunku politycznego, «Studia Politologiczne» 2017, vol. 45.

M. Kolczyński, Niechciany relikt ery premarketingowej w rywalizacji politycznej-nieodpłatne audycje komitetów wyborczych w telewizji publicznej w wyborach do Parlamentu Europejskiego '2019, [w:] M. Kolczyński (red.), Najważniejsze wybory od 1989 roku? Wybory do Parlamentu Europejskiego w 2019 roku: wybrane aspekty kampanii wyborczej, Wydawnictwo Adam Marszałek, Toruń 2019.

M. Kolczyński (red.), Polskiewybory 2014-2015. Kontekst krajowy imiędzynarodowy-przebieg rywalizacji-konsekwencje polityczne, t. 1, Wydawnictwo Uniwersytetu Śląskiego, Katowice 2017.

M. Kułakowska, P. Borowiec, Paweł Ścigaj (red.), Oblicza kampanii wyborczych2015, Wydawnictwo Uniwersytetu Jagiellońskiego, Kraków 2016.

E.M. Marciniak, Relacyjna teoria komunikacji a marketing relacji w polityce, «Studia Politologiczne» 2012, vol. 24.

40 Warto podkreślić, że Konfederacja znakomicie wykorzystała możliwości złożenia pozwów przeciwko TVP w trybie wyborczym, uzyskując nagłośnienie istotnych dla przebiegu kampanii informacji (dotyczących notowań sondażowych partii). 